\title{
Environmental Change and Sustainability of Indigenous Languages in Northern Alaska
}

\author{
Nicholas J. Reo, ${ }^{1}$ Sigvanna Meghan Topkok, ${ }^{2}$ Nicole Kanayurak, ${ }^{3}$ James N. Stanford, ${ }^{4}$ David A. Peterson ${ }^{4}$ \\ and Lindsay J. Whaley ${ }^{4}$
}

(Received 4 April 2018; accepted in revised form 2 April 2019)

\begin{abstract}
Relatively few people under the age of 60 are fluent speakers of the various Indigenous languages of Alaska. Concurrently, climate change is severely impacting Alaska and its residents, where environments are changing far more rapidly than the majority of the planet. These factors complicate the land-language nexus and may have implications for the sustainability of Indigenous languages in Alaska and other parts of the Arctic. In this collaborative, community-centered project, we spoke with Iñupiaq and Yupik language speakers to learn how rapid environmental change affects heritage language discourse practices and how generational gaps in levels of heritage language fluency affect safety and efficacy of customary and traditional land use activities. The results show how local community choices and attitudes are reflecting and constructing dynamic ecologies of language, culture, and environment. Iñupiaq and Yupik languages provide important forms of socio-cultural resilience because they embed the past, yet are inherently dynamic. Community-driven social practices that promote increased local heritage language use can lead to new, creative language domains, new expressions of Indigenous culture, and new Indigenous stances toward a changing environment.
\end{abstract}

Key words: climate change; Indigenous languages; customary and traditional use; resilience; Alaska; Iñupiaq; Yupik; hunting; Indigenous knowledge

RÉSUMÉ. Relativement peu de personnes de moins de 60 ans parlent les diverses langues autochtones de l'Alaska couramment. En même temps, le changement climatique a de fortes incidences sur l'Alaska et ses habitants, où l'environnement change beaucoup plus vite que dans la majorité de la planète. Ces facteurs compliquent le lien entre la terre et la langue, sans compter qu'ils peuvent avoir des répercussions sur la durabilité des langues autochtones en Alaska et dans d'autres régions de l'Arctique. Dans le cadre de ce projet collaboratif axé sur la communauté, nous nous sommes entretenus avec des locuteurs parlant les langues des Iñupiaq et des Yupik afin d'apprendre comment les changements environnementaux rapides influencent les pratiques linguistiques patrimoniales et comment les écarts générationnels en ce qui a trait aux degrés de facilité verbale des langues du patrimoine influent sur la sécurité et l'efficacité des activités habituelles et traditionnelles liées à l'utilisation de la terre. Les résultats de l'étude illustrent comment les choix et les attitudes des gens de la région sont le reflet d'écologies dynamiques en matière de langue, de culture et d'environnement, et comment ils parviennent à former ces écologies. Les langues des Iñupiaq et des Yupik fournissent d'importantes formes de résilience socioculturelle parce qu'elles incorporent le passé tout en étant intrinsèquement dynamiques. Les pratiques sociales communautaires favorisant une utilisation accrue des langues du patrimoine local peuvent finir par engendrer de nouveaux domaines linguistiques créatifs, de nouvelles expressions de la culture autochtone et de nouvelles positions autochtones à l'égard de l'environnement changeant.

Mots clés : changement climatique; langues autochtones; usage habituel et traditionnel; résilience; Alaska; Iñupiaq; Yupik; chasse; connaissances autochtones

Traduit pour la revue Arctic par Nicole Giguère.

\footnotetext{
${ }^{1}$ Corresponding author: Dartmouth College, Native American Studies and Environmental Studies Programs, 37 North Main Street, Hanover, New Hampshire 03755, USA; Nicholas.J.Reo@dartmouth.edu

${ }^{2}$ University of Oregon, School of Law, 1515 Agate Street, Eugene, Oregon 97403, USA

${ }^{3}$ University of Washington, School of Marine and Environmental Affairs, 3707 Brooklyn Avenue NE, Seattle, Washington 98105, USA

${ }^{4}$ Dartmouth College, Linguistics Department, 201 Reed Hall, 15 College Street, Hanover, New Hampshire 03755, USA

(C) The Arctic Institute of North America
} 


\section{INTRODUCTION}

In this paper, we examine the linkages between land and language for Indigenous peoples, that is, the "land-language nexus," which considers recent language loss and accelerated climatic change. To examine this topic, we interviewed 21 local community members in two northern Alaska Native ethnolinguistic groups: the Iñupiat and Saint Lawrence Island (SLI) Yupik. Our project involved collaborative community-centered fieldwork and emphasized Indigenous knowledge of local linguistic ecologies. This project was developed in collaboration with local Iñupiat community members (the second and third co-authors of the paper) and the approval of Iñupiat tribal governments, including the Nome Eskimo Community and the Native Village of Utqiagivik (formerly Barrow). In addition, the project was approved by the Alaska Area Institutional Review Board and the Dartmouth Committee for the Protection of Human Subjects. All authors received formal Institutional Review Board training prior to the project.

We focused our research on the following interrelated questions: How does rapid environmental change in Alaska affect Iñupiaq and SLI Yupik discourse practices; that is, how, when, where, and for what purposes is a language used? How do generational gaps in levels of Iñupiaq and SLI Yupik language fluency affect safety and efficacy of activities surrounding the harvesting, preparing, and consumption of traditional food given recent unpredictability of ice and weather conditions? The results show how local community choices and attitudes are reflecting and constructing dynamic ecologies of language, culture, and environment.

\section{Language Sustainability}

Alaska is home to 20 or more distinct Indigenous languages. The communities of speakers associated with each of these 20-plus languages have experienced a traumatic, forced language shift towards English over approximately the past 200 years. Language shift arises when a community of speakers replaces the use of one language in favor of another. This process has occurred throughout history, but the stunning scope of language loss in the 20th and 21st centuries appears to be without historical precedent. Of the world's approximately 7000 languages, scholars estimate that $35 \%-50 \%$ will cease to exist during the 21st century (Grenoble and Whaley, 1998; Nettle and Romaine, 2000; Harrison, 2007), and some suggest that $90 \%$ of the world's languages may be lost during this time (Hale et al., 1992:7).

In many cases, language shift is due to an encroaching major world language, such as English, Russian, Spanish, or Mandarin. In other cases, it results from contact with regionally or nationally prominent languages. As a minority culture encounters a politically more powerful culture, there are social and economic pressures to assimilate into that culture at the expense of Indigenous lifeways and ways of speaking. The assimilatory pressures are typically institutionalized in formal educational systems where priority is given to teaching in national languages and about national histories.

Over the last 50 years, an increasing number of communities have recognized the value of nurturing the use of their heritage languages, seeing them as a crucial symbol of cultural identity as well as a tool for building and maintaining that identity. Such communities are actively striving for language vitality, revitalization, and ethnolinguistic reclamation (UNESCO Ad Hoc Expert Group on Endangered Languages, 2003; Grenoble and Whaley, 2006; Fitzgerald, 2017). Researchers have documented protective effects of heritage language learning and use for the health and well-being of Indigenous peoples (McIvor et al., 2009) and view language as an important source of resilience, helping communities adapt and thrive under conditions of adversity (Zimmerman et al., 1998; Fitzgerald, 2017). A variety of approaches has been taken to sustain the use of local languages, to expand the number of speakers using the language, and in some remarkable instances, to reintroduce a language into a community where it has not been spoken in some time, such as Miami in Florida (Leonard, 2012) and Wamponoag in Massachusetts (Ash et al., 2001).

A commonly used strategy has been formal classroom learning and adult language education programs, which can help empower community members to achieve their ethnolinguistic goals. One advantage of this approach is that it transforms a social space associated with a regionally dominant language into one where the local language is used. However, formal educational programs require a great deal of capital, both financial and human. Educational materials must be created, teachers trained, and culturally appropriate curricula developed to supplement the topics mandated by school districts or ministries of education. Not uncommonly, national educational policies are at odds with the goal of promoting local language use, so curriculum development can be a politically sensitive issue (Hornberger, 1998; Grimes, 2001). Primary and secondary teachers are under pressure to meet state and national education standards of achievement and accountability, while university language classes are shaped by accreditation requirements. In either case, teachers can feel pressured to follow long-established, classroombased language education models. As a result, a traditional classroom can be a difficult environment to foster experiential, naturalistic, socially interactive languagelearning. For these and other reasons, alternative models are frequently adopted.

Perhaps the most acclaimed method is the language nest approach, which has the advantage of focusing on young children during their prime language-learning years (Grenoble and Whaley, 1998). The Māori people of New Zealand pioneered these community-based immersion programs ( $k \bar{o}$ hanga reo) where young children have daily interpersonal encounters with Elders who are fluent in 


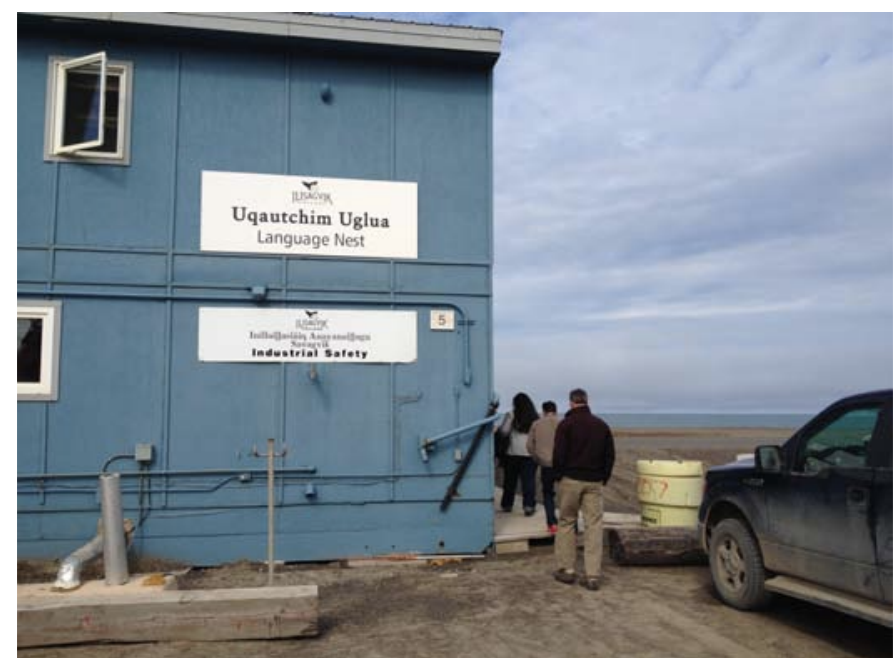

FIG. 1. Visiting an Iñupiaq language nest on the shores of the Arctic Ocean, Utqiagivik, Alaska.

Māori language and culture. Following the success of the Māori programs, the language nest initiative has now spread to many other Indigenous communities, starting from neighboring Polynesian languages (e.g., Hawaiian), then to the continental United States (e.g., Cherokee, Mohawk, Lakota, Choctaw), and now extending around the world. For example, on a recent visit to Utqiagvik, Alaska, we had the privilege of learning about an Iñupiaq language nest that serves local children on the shores of the Arctic Ocean (Fig. 1), which highlights the far-reaching effects of the Māori initiative.

Other relatively successful approaches include the master-apprentice, or mentor-apprentice model, which can be effective in smaller communities where a language nest program may be more difficult to develop. In these oneon-one mentoring relationships, an Elder regularly meets with a younger member of the community, passing along cultural and linguistic knowledge (e.g., McIvor and Rorick, 2017). Other communities are trying a combination of these methods as well as tapping into locally relevant cultural activities in language learning.

For these Indigenous initiatives around the world, one of the clearest findings is that local language use is most likely to be sustained or extended when it is naturally and holistically connected to as many aspects of the daily life of the community as possible (Grenoble and Whaley, 2006). To achieve long-term sustainability, a community's identity must be in a constant positive state of three-part reinforcement-language, culture, and environmentfostering natural development and support (Romaine, 2008; Stanford and Whaley, 2010). This reality poses a practical challenge in the case of the Iñupiaq and Yupik languages of northern Alaska, since the three-part reinforcement has been disrupted in the past, resulting in an overall shift towards English. Reversing this shift entails developing social practices that reemphasize the links between language, culture, and environment while also adapting to a changing social and environmental landscape.

\section{Study Area and High Latitude Environmental Change}

Temperatures within the Earth's Arctic regions have risen $0.6^{\circ} \mathrm{C}$ per decade over the last 30 years, twice as fast as the global average (IPCC, 2013). Alaska has warmed twice as fast as the rest of the U.S., bringing widespread impacts. Arctic summer sea ice is receding rapidly and could disappear before mid-century (Stroeve et al., 2012). This change is altering marine ecosystems, impacting winter coastal hunting grounds for Iñupiat and Yupik, and leading to increased community vulnerability to coastal erosion. Thawing permafrost is leading to more wildfires, and is affecting infrastructure and wildlife habitat (Euskirchen et al., 2006). Rising ocean temperatures and acidification will alter valuable marine fisheries (Sumaila et al., 2011).

The cumulative effects of these climate-driven changes in Alaska strongly affect Native communities that rely closely on the various Alaskan environments for activities surrounding the harvesting, preparing, and consumption of traditional food, maintenance of social structures, and as a foundation of cultural identities (Chapin et al., 2014). Arctic and sub-Arctic communities have adapted well to high natural variability in climate, wildlife dynamics, and land change throughout history (e.g., Forbes et al., 2009). Locals in the North Slope and Bering Strait regions of Alaska are highly resilient and adaptive, but the rate and magnitude of environmental change in recent decades challenges their adaptive capacity (Hovelsrud et al., 2011).

In the North Slope region of Alaska, above the Arctic Circle, changes in sea ice, snow cover, lake and river ice, and permafrost, are affecting Indigenous food traditions and livelihoods. The annual end of snowmelt in Utqiagivik, Alaska, has become increasingly variable with a trend toward an earlier snow free season. In Utqiagivik, these changes are impacting spring goose hunting, which depends on the presence of inland snow cover (Hinzman et al., 2005). The extent and predictability of shore fast and nearshore ice are declining, impacting safety and efficacy for the Iñupiat hunters (George et al., 2004). Daily wind speeds are also changing in ways that impact local livelihoods. Hunters in Wainwright, Alaska, are experiencing fewer days than in previous decades with wind conditions suitable for safely hunting bowhead whales (Hansen et al., 2013).

In the Bering Strait region between the Chukchi and Bering Seas, increased winds, increased storm frequency and severity, increased erosion, and diminished sea ice threaten the low-lying areas with habitual flooding (Marino, 2012). Coastal communities and communities situated along rivers in this tundra-dominated region are being impacted by erosion resulting from increasingly powerful storms, storm surges, and thawing of permafrost. For hunters in Kivalina, Kotzebue, and Shishmaref, Alaska, decreased hunting opportunities are placing stress on local livelihoods and food systems. Spring migrations, and thus hunting opportunities, used to last for two months. Now, spring migrations are compressed into a two-week 
or shorter period. Hunters are also experiencing reduced hunting opportunities in the fall season due to more frequent fall storms (Huntington et al., 2016).

\section{MATERIALS AND METHODS}

We conducted open-ended ethnographic interviews with 21 different Iñupiaq and SLI Yupik language speakers plus one Central Yup'ik speaker in the communities of Utqiagivik and Nome, Alaska. These interviews were supported by three years of informal conversations and participatory ethnographic research. Co-authors Nicole Kanayurak (Iñupiaq) and Sigvanna Meghan Topkok (Iñupiaq) are conversant in Iñupiaq and conducted the interviews, while the other co-authors helped to develop the research approach and analysis of data. Following the pattern of language usage in these communities (see Domains of Usage and Discursive Practices), we conducted the interviews primarily in English, although some sections included Iñupiaq language and one interview was conducted entirely in Iñupiaq. We began our interviews broadly, asking questions about individuals' upbringing, career paths, and educational experiences. We then discussed Indigenous language use and awareness of local environmental change. The interviews ranged from 20 minutes to 2 hours, were guided by an openended interview guide that we developed for the project (Table 1), and were digitally recorded and transcribed. We interviewed 8 men and 13 women whose ages ranged from 24 to 71 . Interviewees were identified as community members respected for their knowledge of Iñupiaq or SLI Yupik language, culture, and local history. Our interview participants included first language (i.e., native) speakers, as well as language learners. All interviewees had a good command of their heritage language and could be characterized as fluent or nearly fluent speakers. They have worked in a wide range of occupations including: culture and lands specialists, heritage language specialists/ teachers, community planners, researchers, clergy, nonprofit leaders, retirees, and natural resource managers. Although all interviews were conducted in the towns of Nome and Utqiagivik, interviewees hailed from a wide range of towns and Native villages in northern Alaska where Iñupiaq or SLI Yupik continue to be spoken.

\section{RESULTS AND DISCUSSION}

\section{Language in Alaska Native Societies}

We frame our interview results in the socio-historical and sociolinguistic context of these communities. In 1998, the Alaska legislature passed a bill codifying English as the official language of the state. Less than two decades later, that bill was amended to include 20 Native languages as being co-official with English in recognition of their widespread use and the importance of Indigenous peoples to the history and future of Alaska. Of these 20 languages, 16 distinct Indigenous languages continue to play central roles in everyday life in villages throughout the state (Barnhardt and Kawagley, 2005) (Fig. 2). Although recognition of the presence and importance of Alaska Native languages has increased dramatically in recent years, it is also clear that the shift towards English is ever present. Census data indicate that regular use of Alaska Native languages drops by over half when comparing young school-aged children to those over 65 (Krauss, 2007).

Even so, Indigenous languages are integral to Indigenous communities and cultures. The history of a people, as well as their cultural values and interactions with their environment, slowly accrete in language over time. For this reason, the language becomes particularly adept in supporting culturally specific activities, verbal art, and group identity. An awareness of this fact was clearly present with the Iñupiat and Yupik we interviewed, who regard their original languages as central to their cultural identity. As an Iñupiaq language teacher from Utqiaġvik stated plainly, "Our language is who we are."

The centrality of language to cultural identity helps to explain the significance of the trauma that occurred when Alaska Natives were forced to stop using their original languages during the assimilation era of the U.S. federal Indian policy. United States assimilation policies aimed to "kill the Indian in him, and save the man" (Capt. Richard H. Pratt, founder of the Carlisle boarding school, 1892). A primary strategy for achieving this goal was to send Native children to boarding schools, attempting to recast Native youth in the likeness of Western European children by separating them from family and community, introducing Christian-based religion, and replacing Indigenous languages with English (Barnhardt, 2001). As an administrator of an Alaska Native service organization put it, "Imagine if all Americans were now required to speak only in French, and what that would do to our sense of being American." This individual recalled an Inuit Elder stating that being forced to stop using their language was like "having our tongues ripped out." An Iñupiat government official from the North Slope Borough shared, "We were expected to learn English. I mean, I can recall when they're just getting into the third grade and spoke Iñupiaq in the room you'd get a slap on the hand with a ruler for speaking Iñupiaq and they were trying to keep us from doing that to learn better English." These psychologically and, at times, physically brutal assimilation efforts caused significant trauma for Native peoples and are important context for any contemporary discussion regarding Indigenous languages in the U.S. and Canada.

One explanation for the centrality of Iñupiaq and SLI Yupik for group identity is that the structure and composition of these Indigenous languages have developed over many centuries to articulate Indigenous worldviews, values, conceptualizations, and knowledge (Treuer, 2001; Simpson, 2004). According to the Iñupiaq and SLI Yupik 


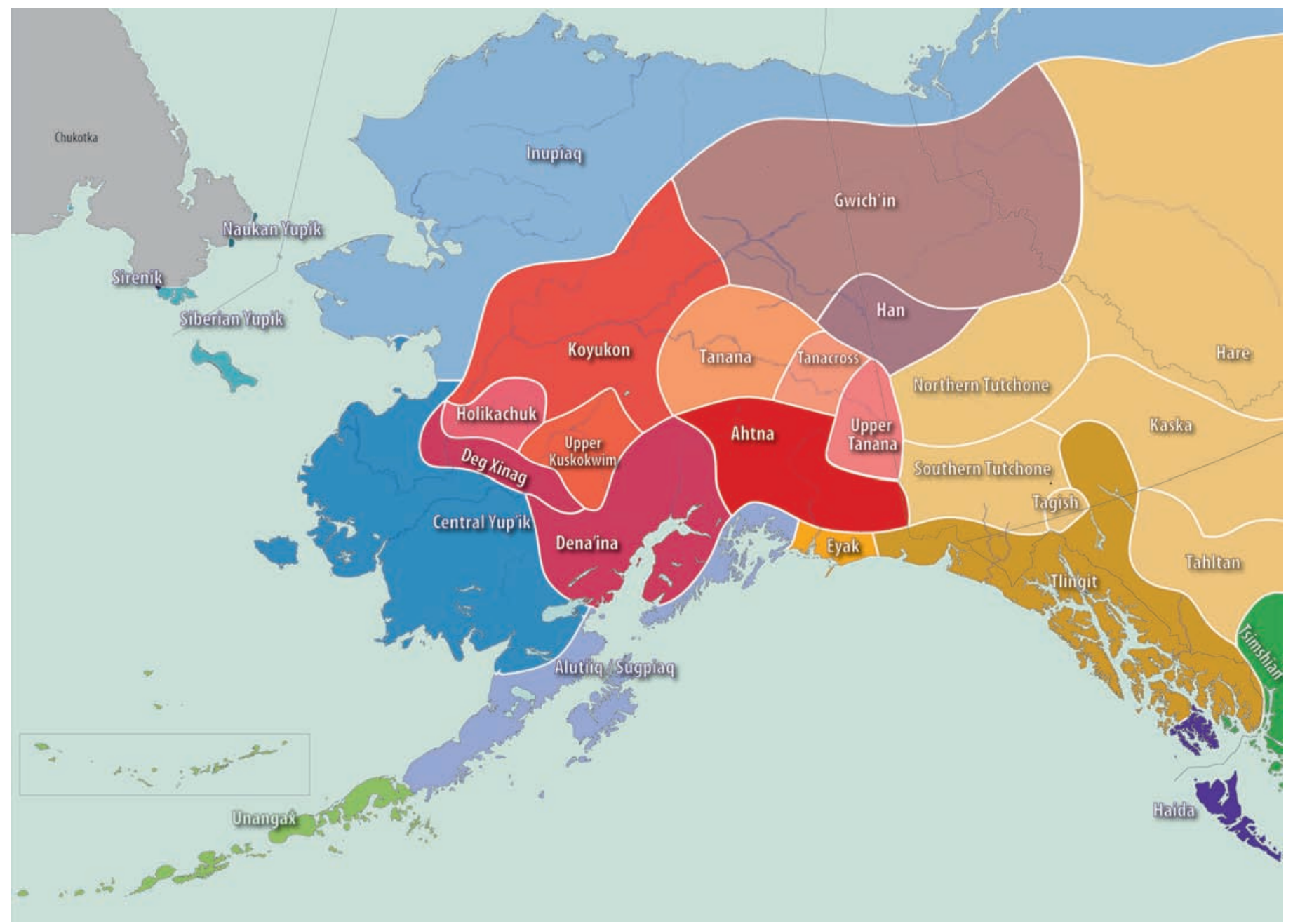

FIG. 2. Indigenous peoples and languages of Alaska. Reproduced with permission from Krauss et al., 2011.

language speakers we consulted with, using their languages while participating in cultural activities, such as harvesting and preparing traditional and wild foods, makes the experience feel specifically Iñupiaq or Yupik-in other words, to feel more of their own culture. For example, a Savoonga service organization administrator explained: "There is a difference ... when we practice our cultural values and our traditions and we're also using our traditional language, it feels so much more authentic." There is a sense in the communities that Indigenous languages help make the community whole and enhance their well-being. A female Elder from Kotzebue similarly noted, “... when they were busy berry-picking or whatever, they're all talking in Iñupiaq, you know ... and that makes it more-makes me feel better ... it really makes me feel good.” According to the SLI Yupik woman from Savoonga (quoted above), language "builds a strong cultural foundation for a strong identity, and that's definitely a tool and a medicine to make sure that we live a prosperous and healthy life. Language is key." Iñupiaq and Yupik languages are more than just a means of communication or a matter of food security, "[they're] also about feeding your soul, your spirituality."
Indigenous languages are also fundamental components of Indigenous knowledge systems (Kimmerer, 2002; Maffi, 2005). Indigenous knowledge comes from the land through the relationships Indigenous peoples develop with the essential forces of nature (Youngblood Henderson, 2000; Simpson, 2004) - until recently, relationships that were enacted solely using Indigenous languages in Alaska Native communities.

\section{Recent Societal Change}

Globally, patterns of settler colonialism involved breaking up Indigenous social structures and cultural traditions, including Indigenous languages in order to access territory (Wolfe, 2006). Ongoing processes of settler colonialism include systemic underdevelopment of Indigenous communities in the wake of economic and political transformation (Jorgensen, 1978). For Indigenous peoples in the contiguous United States and southern Canada, these societal transformations occurred over the past few centuries, although settler colonialism is an ongoing process. By contrast, within Arctic portions of the U.S. and Canada, major societal transformations have 
TABLE 1. Questions used to guide open-ended ethnographic interviews.

\begin{tabular}{ll}
\hline \hline Demographics & Age? \\
& Hometown? \\
& Other places you have lived? \\
& Tribal affiliation? \\
& Eccupation? \\
& Education? \\
Personal language use & How often do you speak your language? \\
& Who do you speak your language with? \\
& When and where do you speak it? \\
Language status and future prospects & Do younger people in the community use and understand the language? \\
& Are there differences between language being spoken by younger and older community members? \\
& How are the relationships between youth and Elders in your community these days? \\
& What is the role or importance of your language in the community today? \\
& Have any environmental conditions changed in your lifetime in your hometown? \\
Environmental change & If so, how have these changes affected you? \\
& Do these environmental changes affect when, where, how you use your language? \\
\hline \hline
\end{tabular}

occurred within the lifetime of today's Elders, or since around the 1950s (Watt-Cloutier, 2015).

Alaskan Indigenous peoples have experienced rapid and pronounced socio-cultural change over the last 70 years, including shifts from Iñupiaq/SLI Yupik to English as the primary language in most households (although this is occurring at slower rates among SLI Yupik), imposition of Euro-American educational systems including boarding schools, and transition from predominantly subsistence economies to mixed economies where wage labor features prominently. As one of our interviewees, a professor of Iñupiaq at a state university, put it: these changes have "upended the social order of things" in Alaska Native villages. Other authors have previously linked these rapid social changes with health disparities, high suicide rates (Tester and McNicoll, 2004; Curtis et al., 2005), and other forms of trauma (Barnhardt, 2001; Easley and Kanaqlak, 2005). It should be noted that in the present study, we use the term "customary and traditional use," rather than "subsistence," to mean the activities traditionally undertaken by the Indigenous peoples of Alaska to provide for their families, such as hunting, picking berries and greens, and gathering roots and eggs. The term "subsistence" can signify that people merely "subsist" in the sense of achieving bare minimums to survive. A lifestyle that enfolds customary and traditional land uses, in the eyes of many participants in this study, is a good life and customary or traditional foods are preferable to most store-bought foods. The foods that are hunted, butchered, processed, picked, and stored give holistic sustenance to Iñupiaq and Yupik people, nourishing all aspects of their existence. In this way, their whole way of life, beliefs, customs, and traditions are dependent upon direct connections with their environment.

Through our interviews, we learned one way these changes are playing out at the household-level, whereby Alaska Native families are pressured to spend time out of the home and away from family. A representative from a wildlife co-management agency pointed out that young people get mixed signals between home and school, which impacts their social development. For instance, at home they may be taught to listen more and talk less when interacting with an Elder. But in school, teachers instruct students to speak up, share their ideas, and make strong arguments in class discussions (Trumbull et al., 2001).

Furthermore, we learned that adults, particularly parents of young children, are forced to choose between working for wages outside of the home or staying home with their children. If they choose to work within the wage economy, they can more easily pay bills and pursue career and certain types of community development goals. But according to our interviewees, this work comes at the cost of spending far less time with children and leads to generational gaps in language, communication, and values. An Iñupiaq official from the North Slope Borough shared, "When parents are employed, they start work early in the morning before the children get up to go to school, and so [children] don't get to see their parents throughout the day until late in the evening. And that takes the educational opportunity from them to learn basic stuff [through] the conversations you have on a daily basis with your family."

In terms of language use, Alaska Native youth are less fluent in their Indigenous languages than their parents and grandparents (Krauss, 2007). The Elders we spoke with described the youth as "bilingual," but they did not mean that the youth are fluent in both English and their Indigenous language. Rather, they were describing the tendency of youth to blend English and Iñupiaq/SLI Yupik into an English-heavy mixture. When youth speak their Indigenous languages, they use incomplete sentences and slang, as opposed to the "high language" (a term used by two of our Iñuiat interviewees) of their Elders. The lack of Indigenous language fluency among Alaskan youth creates communication barriers between the youth and Elder members of their families and communities. 

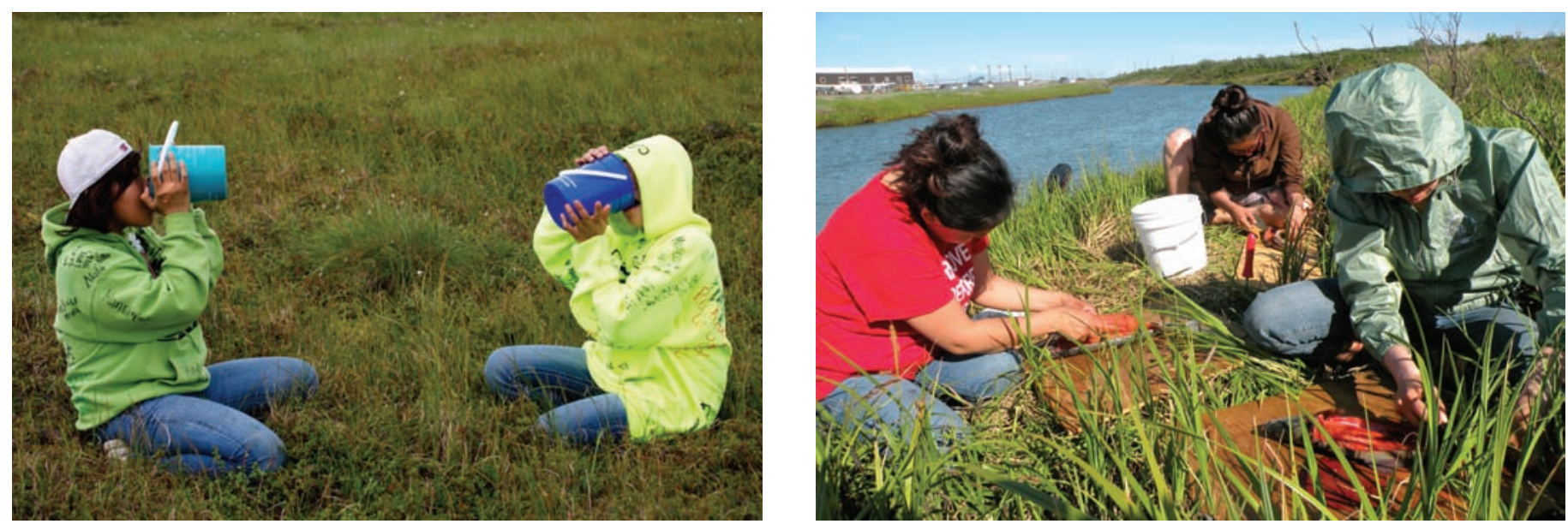

FIG. 3. St. Lawrence Island youth berry-picking near Nome, Alaska (left). Women cutting fish in Nome, Alaska (right).

\section{Land-Language Nexus}

For SLI Yupik and Iñupiat, the land (and ice), Indigenous lifeways, cultural identity, and Indigenous languages are all tightly bound together. The community members we spoke to explained that any impacts to the environment, to Indigenous language use, or to culturally specific lifeways concurrently have an effect upon the other two elements of community life since all three are intertwined. For this reason, climate change, a stark reality in high latitude regions, brings about changes to many aspects of community life, including language use. As a university professor of Iñupiaq, originally from Utqiagivik, put it: "One thing is for certain, Inuit all across the Arctic have observed dramatic changes in climate. It's affecting everything about us. It's affecting our wildlife, it's affecting our language, it's affecting the behavior of people, and it's affecting the kind of relationships people are living today."

\section{Reduced Access to Traditional Foods}

Doing things out on the land with extended family, such as gathering wild foods, can create ideal environments for teaching and learning Yupik and Iñupiaq languages and traditional values (Fig. 3). Activities like whaling and berry picking require use of specialized vocabulary concerning weather, ice, currents, and wildlife (Gearheard et al., 2013). As one Elder from Utqiagvik summarized, "Iñupiaq is a language of being out on the ice." Nearly everyone we spoke to mentioned that teaching language and values happens best while actively doing things together in larger groups.

However, rapid environmental change in northern Alaska has made it increasingly challenging to safely engage in customary and traditional land-use activities (Brinkman et al., 2016). An Iñupiaq language instructor from Utqiaġvik wondered, "How are we gonna explain these different ices to the next generations? How are we gonna talk about hunting and things to look out for if it so happens that the ice comes back? What are they gonna do?" Another interviewee shared that skins are used less for clothing and boats because they tend to be overtaken by mold and mildew now that the wet season lasts much longer.

Contexts surrounding customary and traditional land uses (i.e., contexts surrounding the harvesting, preparing, and consumption of wild/traditional foods) bring urgency to understanding traditional values, where listening closely to an Elder and to the surrounding environment can be crucial for a person's safety, given risks of wildlife encounters and falling into deadly, cold waters. However, some traditional values are harder to reinforce using English; SLI Yupik and Iñupiaq rely on specialized vocabulary, body language, and other subtle forms of communication within the linguistic system to reinforce values. These are lacking in English. A young wildlife professional explained that it would be hard to express in English how a younger person shows respect to an Elder. In Yupik, there are straightforward ways of describing this. We heard similar sentiments regarding Iñupiaq. Therefore, climate-driven environmental changes, which create obstacles for Inupiaq and Yupik hunters and plant gatherers, may also create obstacles for passing on language and Indigenous values.

\section{Heritage Language Fluency and Hunter Safety}

A primary way that climate change affects Iñupiaq and Yupik customary and traditional land uses is by making these activities altogether less safe. Shore fast and nearshore ice are far less stable and predictable for marine mammal hunters. Weather is also less predictable than it was historically or in the recent past, limiting the number of days hunters and plant gatherers can get out, and endangering them while they are gathering wild foods. The various ways that climate change threatens the safety of Indigenous hunters in northern Alaska is relatively well documented (George et al., 2004; Gearheard et al., 2006; Huntington et al., 2016). A factor that is not as well documented, but came up regularly in our interviews, is the possibility that a generation gap in heritage language fluency creates additional safety issues for hunters and wild plant gatherers. 
The Iñupiat and Yupik we spoke with shared that their Indigenous languages are much more precise concerning environmental conditions, geography, plants, and animals. Thus, there is less confusion when using Native languages while hunting and more opportunity for misunderstanding or need for lengthy descriptions in English. As one male Iñupiaq Elder from Utqiaġvik explained, "When we're out hunting, most of the time, we speak Iñupiaq, the words that we use for different conditions of ice, currents, wind, where different groups are in relation to where we're hunting. It's much easier to speak in Iñupiaq, and kind of know now where things are, how things are." Another Elder from the same community shared, "So we use Iñupiaq language to communicate our location and our conditions. Not only our conditions, but the atmospheric and the oceanographic information as well. It's all done in Iñupiaq ... We have to now switch to English to make the younger generation understand."

In our interviews, Yupik and Inupiaq languages and speech patterns were described as being very direct, so listeners know exactly what someone is asking or telling them to do, and it is easy to grasp the urgency of directives. With mixed language crews however, fluent heritage language speakers may have to explain things twice, once in English and once in their original language, and directives are perceived differently depending on the language being used. An Iñupiat official from the North Slope Borough explained, "So that's the thing I've learned over time that our Iñupiaq language is very direct 'cause of the activities that we're involved in. When you're told something to do by our parents, you get it done in a very short period of time and do it in the right manner without any mistakes or anything like that. But when you talk to children in the English they have different understandings. They take their time. The work that you want them to accomplish doesn't get done right away. And that kind of directiveness [sic] is lost."

Hunting and gathering wild plants in northern Alaska involves many risks, including exposure (cold weather), contact with dangerous wildlife, and the possibility of falling through sea ice. Managing these risks requires fluid communication and swift decision-making in response to changing conditions. Hunting and gathering parties who have to use strictly English or a blended heritagelanguage-English may be less well equipped to deal with risks because their communication is slowed, and because English is experienced as a less direct language than either Iñupiaq or SLI Yupik.

\section{Domains of Usage and Discursive Practices}

Our interview questions also focused on issues of Indigenous language use. While it is clear from our interviews that climate change is not a significant causal factor in Iñupiaq's endangerment, it is aggravating an already dire situation.

Community members provided ample evidence of grammatical proficiency attrition among the younger generations, including a few passing comments concerning the sound system of the language. A female Elder from Savoonga noted, "The special guttural and nasal sounds; I think the young people don't know how to make those." A younger Iñupiaq woman from Nome confessed that, "I speak Iñupiaq with an English tone." However, there is a clear perception that the structure of Iñupiaq has changed, in what is depicted by most community members as a language mixture. As one speaker commented, "To speak it with anybody younger than 70 , they do not have that language skill. And the variety of language usage has gone down. So, I see a mixture of - today it's a mixture of Iñupiaq and English." Many other accounts also reflected this state of affairs. A female Iñupiaq Elder from Noorvik expressed her thoughts about blended language use, saying, "Otherwise, it's broken. English and Iñupiaq mixed together doesn't make it Inupiaq." A younger speaker who formally studied the language at the university level made a more pointed assessment of where attrition is occurring: "I think it's less probably grammatically correct the way we speak because we don't understand the grammar structures, like how to put words together properly. We understand, oh, the base word of this means that, and so we might use it just because we know what it means. But we don't know the little in-betweens that make a sentence." Presumably, the "little in-betweens" the speaker referred to are the complex noun and verb inflections that characterize the Iñupiaq of older generations.

This attrition appears to have occurred due to a variety of factors. Most important among these is the boarding school experience, which left speakers with feelings of inadequacy in their language proficiency and concern for what suffering their own children might experience if they transmitted the language to them. As one younger speaker observed, "I know one of the things that I hear often is like, 'I was forbidden for a while,' so they were traumatized and they didn't want that [same trauma] for their kids. But, I also feel like they think they don't know it [the language] now. They don't know enough of it to teach, and they don't want to teach wrong because it goes against our cultural values to teach something wrong." The traumatic experience of this generation, and the resulting lack of perfect transmission to the next, is compounded by a seeming ambivalence in the available school instruction. Heritage language education does not focus on the ideal age range and fails to make full use of available financial and pedagogical resources. More than one of our interviewees commented on the role school has had in robbing children of opportunities to be exposed to the language at home or in other settings. Clearly, whatever the ultimate causes, modern schools are not perceived as doing enough to revitalize the language.

With this situation in mind, it is only natural that the number of domains (Fishman, 1965) that the language can be effectively used in has decreased substantially from what it was in the past. Changing climate conditions are leading to changes in the environmental phenomena that need to be referenced in language, leading at least one respondent 
to express concern for the potential loss of these words and their associated concepts. More significant, as stated earlier, is the fact that due to lack of language proficiency among younger hunters and gatherers, English forces its way into these domains as well: the mixture of proficiency levels leads to loss of domains for Indigenous language use. Concern for the inclusion of non-proficient speakers leads to the infiltration of English even in the last domains where the language otherwise appears safe, such as within customary and traditional activities:

When I'm in Kotzebue and I go with my relatives to go berry-picking, or go pick greens, or go fishing or whatever, everybody's around talking in Iñupiaq. They're all conversing in Iñupiaq. You don't hardly hear any English unless they tell their kids to, 'Hey, knock it off,' or, 'Don't go close to the water,' or whatever. But when they were busy berry-picking or whatever, they're all talking in Iñupiaq, you know.

(female Elder from Kotzebue)

An Iñupiaq speaker from Noorvik described a similar situation in the domain of the church:

Once a week, they have Elders come together, and they study the Bible, and they sing the songs, but they also invite community members to come and listen and learn the songs or learn about the Bible-learn about God. It's done in Iñupiaq. If you don't know how to speak it, you're just sitting there listening to the words, which is good because then you're able to hear how part of that is put. When they started getting younger people though, they had somebody on the sideline to interpret what they were saying, or they would follow the Bible. The younger people would know where they're at and be able to hear what the words are saying and what they mean.

While Iñupiaq is still used in this type of situation today, English could easily displace Indigenous language in these domains as well.

Other interviews revealed the shrinkage of domains for language use in different respects. One interviewee expressed regret at the loss of Indigenous television programming:

Those have been cut out. Everything Inuit has been cut out - out of the TV. The radio stations that we set up to be radio stations for Inuit are no longer Inuit; they're all white people, white language, other languages except Inuit language.

(Iñupiaq university professor, originally from Utqiagivik)

Another community member described the loss of the language in a traditional musical genre:

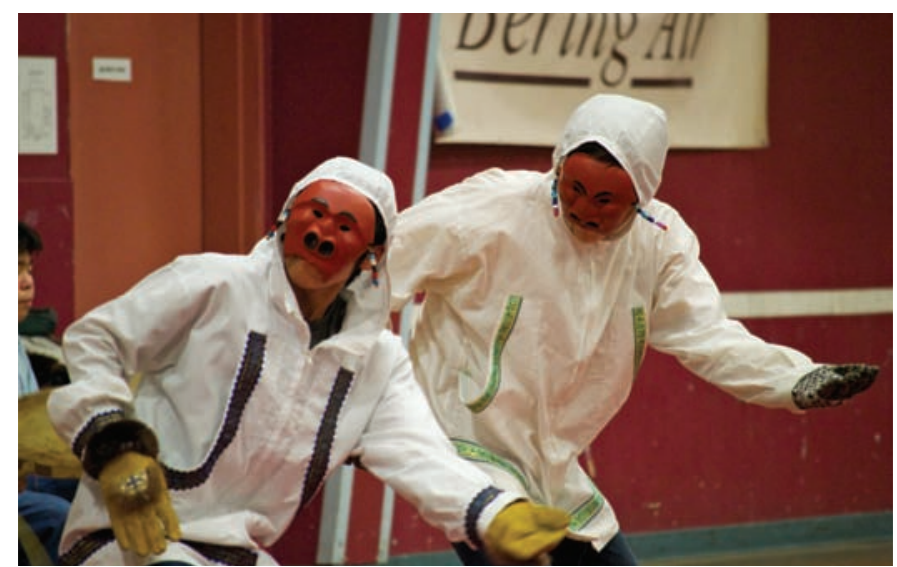

FIG. 4. King Island Dancers performing a "Noisy Twins Dance."

King Island men or people, I guess, back then-I'm not sure of this - the successful hunter composes a new song, a new polar bear song. And those songs are now used for invitational dances for welcome dances. It's what we call them when we perform. So that practice has-is just about lost.

(Iñupiaq female Elder from Nome, Fig. 4)

The loss of traditional domains for language use is further implied by the following statement by an Iñupiaq pastor:

Some of the ways that training used to happen [has been lost] ... the differences of young men interacting with the other folks in a work setting, an everyday work setting, where the guys would be working on sleds, working on carving, whatever they happened to be working on, that pertained to everyday life. The young folks would see how that was done and be able to ask questions, or if not ask questions, at least observe how things were done.

One striking example of the way English has usurped the traditional domains of Iñupiaq discourse is in two independent accounts of issuing instructions to children. The first account, detailed earlier in our paper, concerns the directness of Iñupiaq and the different ways that children respond to directives given in Iñupiaq versus English. Another speaker described a specific change in language use patterns across generations. They started by describing an Elder from their parents' generation:

... they were raised by their grandparents and they would only speak Iñupiaq and when they were really in trouble, they would say English words. And that meant so much. And I feel like it's vice-a-versa. 'Cause when I get in trouble, my mom just screams in Iñupiaq and I'm like, whoa man, I need to pay attention and this is real.

(Younger Iñupiaq speaker from Nome) 
What these accounts indicate is that while in previous generations speakers may have used English in contexts where they are emphatically issuing instructions, as a kind of unexpected attention-getter, nowadays the situation has reversed, and it is use of (unexpected) Iñupiaq that has the desired effect.

Throughout the interviews, there is thus a constant reminder of the contraction of domains, a phenomenon that is well known to linguists as a sign of progressive language shift (Gal, 1979; Dorian, 1981; Fishman, 1991). The same young speaker who identified the specific aspects of grammatical attrition also proposed the potential remedy for the situation going forward, including a direct reference to the notion of domain:

I think more parents need to learn to speak, because unless the kids who are learning in the school system can come home and speak to their parents in that language to practice, it would be difficult for that to stick. They might learn it, and they might not be accustomed to using the language outside of the classroom. And it just becomes this 'it's only for that setting' kind of thing. But it needs to be for everything you do, for when you talk to your friends on the phone and when you text, when you are in a meeting with other people, whatever else it needs to be.

(younger Yupik woman)

There is furthermore a recurrent theme of respect in our interviews. Elders often lament how the younger generation fails to exhibit this key feature of discourse. As one speaker put it:

And the younger generations don't know that [how to show respect] because they haven't been spoken to in the language. If you speak our Alaska Native languages, they're very observational languages. Part of knowing how to speak Iñupiaq is we know how to read people. So much of our language is observational. So there's a lot of nonverbal cues that we pick up.

(female Iñupiaq Elder from Nome)

From this quote, it would seem that in part this notion of respect relates to indirectness or the use of nonverbal cues. Another speaker's assessment also relates respect to pacing:

That they just get impatient. Like, 'okay well just tell me the story already.' But, you can't really just tell a story 'cause you have to have primer and get into it fully, 'cause these stories are part of our souls, we can't just give it away real quick. You know, so I think that's the relationship right now, is there's a cultural difference. In etiquette, in pace, in everything ... I try to teach my kids at high school how to talk to Elders as much as I know because I've got scolded many times. For talking too fast, like now I'm talking really fast, I'm talking English pace.

(younger Iñupiaq speaker from Nome)
Additional aspects of this notion of respect appear in other excerpts:

... it's almost like shy, but it's not. It's like a respectful shyness. You're being timid. You're not having this demanding presence. You're just kind of there, and you don't speak to them unless they speak to you kind of thing. Etiquette things that, first of all, if the Elders don't speak English, they can't tell you about them unless you know the language. So there's this communication barrier in learning those values.

(young female Yupik speaker)

The cause cited for this difference is usually the emphasis put on outspokenness and curiosity-the positive state of engagement, valued in the modern Western education system. The same Central Yupik speaker explained, "In Western kind of context in the classroom, you're encouraged to be more outspoken and more vocal, less shy. So there's these two different values of how you're supposed to act." These statements indicate that not only is English displacing the Indigenous languages within important domains of usage, but there is also evidence that a more fundamental displacement of aspects of Iñupiaq and SLI Yupik stylistics is underway.

\section{CONCLUSIONS}

Our interviews highlight the crucial links between language, culture, and identity in northern Native Alaska. These connections comprise a dynamic ecology that is evident in community members' attitudes and stances toward language. Major societal changes have occurred in northern Alaska within the lifetime of today's living Elders. The dominance of English usage over SLI Yupik and Iñupiaq in many settings is both a cause and a result of this "upending of the social order of things," as one interviewee put it. Transmission of traditional values is impacted by the generation gap in heritage language fluency because Elders are unable or unwilling to teach values, such as culturally specific ways of showing respect to Elders or to wildlife, in English-dominated domains.

A theme that emerged through our interview conversations is that language is a key link between safety on the land and resiliency and adaptability in a time of changing climates. The knowledge encoded in heritage languages from the observations of ancestors has been built up over thousands of years, and losing access to these languages could mean losing links to that knowledge and ways of viewing and understanding the surrounding environment. Environmental changes in northern Alaska are reducing Yupik and Iñupiat people's access to traditional foods (Brinkman et al., 2016) and impacting their language use and learning. Hunting, fishing, and gathering wild plants are social activities and the time spent on the land, on the ice, and in the kitchen involves important domains for 
speaking SLI Yupik and Iñupiaq languages. Reduced access to traditional foods is thus an important form of domain contraction, a process that indicates progressive language shift (Gal, 1979; Dorian, 1981; Fishman, 1991). One cause of restricted access to wild foods is that climate change is creating heightened safety issues for hunters and wild plant gatherers, something that has been well documented in other studies (George et al., 2004; Gearheard et al., 2006; Huntington et al., 2016). But our findings indicate that the generational gap in heritage language fluency and infiltration of English into customary and traditional land use domains creates additional safety concerns. Yupik and Iñupiaq languages are languages that have elaborate lexica to describe ice, and their specialized local vocabularies are suited to the local customary and traditional land-use activities - where split-second decisions are often required. The use of English, which our interviewees perceive to be a less direct or efficient language, could be compounding already concerning safety issues for hunters and plant gatherers.

In many cases, when our interviewees discussed directness or efficiency of Yupik and Iñupiaq, they were referring to specialized vocabulary. The notion that Indigenous Alaskan languages have numerous expressions for snow in particular, has been a topic of some controversy and confusion in popular media accounts (see Pullum, 1991; Kaplan, 2003; Krupnik and Müller-Wille, 2010). In this paper, we focus more generally on the communicative efficiency of these northern Indigenous languages (Regier et al., 2016), and vocabulary plays a crucial role. It is clear that Yupik and Iñupiaq have diverse and specialized vocabularies that lead to efficient communication during customary and traditional land-use activities. As others have reported, such vocabulary differences apply not only to language associated with snow and ice, but also to language tied to weather, ocean currents, and animal migration (Krupnik et al., 2010). In this respect then, our interviewees' experiences of language and safety may stem from a combination of Yupik and Iñupiaq being highly attuned to the environments in northern Alaska, along with the fact that speakers from different generations have different levels of fluency and different usage patterns. Safety issues arise largely when hunting groups have a mix of individuals who are most comfortable communicating either in English or in one of the Indigenous languages, and when these groups are having to respond very quickly to dynamic weather patterns or ice conditions, in essence, bilingually.

The three-part linkage between heritage languages, cultural identity, and the environment is further impacted by the practical everyday need to rely on the land to put food on the table. Because of the high costs of living and the limited availability of fresh fruits and vegetables, many households continue to rely heavily on traditional/ wild foods for nourishment-physically, spiritually, and culturally (in Iñupiaq these foods are termed niqipiaq or nigipiaq, depending on dialect, meaning "real food").
Sharing foods harvested from the land over dinner creates a valuable dynamic in these communities. It encourages the use of Iñupiaq words for the foods, stories of hunting and the land, recognition of traditional values, and appreciation for the land, animals, and those who provided the food.

Our findings add to previous research indicating that Indigenous languages can provide important forms of adaptive capacity in Indigenous communities (Zimmerman et al., 1998; Chandler and Lalonde, 2008; McIvor et al., 2009). Our study indicates that language and identity are critical sources of resilience for SLI Yupik and Iñupiat in the rapidly changing environments of northern Alaska. Resilience means drawing on the past, such as the specific knowledges, values, and ways of being that are the product of a group's genealogy, and reimagining them in a changing context in ways that allow communities to adapt or thrive under adversity (Fitzgerald, 2017). Language, by its very nature, is an important source of resilience since it embeds the past, but is inherently dynamic. Though the shift to English is clear, these communities' heritage languages remain vibrant and are vital tools for navigating socioenvironmental change. Our field interviews show how language, culture, and environment are linked together in an ecology that has dramatically shifted during the lifetimes of our interviewees. But our interviews also suggest that Indigenous groups understand these same linkages as foundational to their pathways forward in a rapidly changing Arctic. Community-driven social practices that promote increased local cultural engagement, including activities surrounding the harvesting, preparing, and consumption of traditional foods, can lead to new, creative domains for Indigenous language, new expressions of Indigenous culture, and new ways of facing the challenges presented by rapid environmental change.

\section{ACKNOWLEDGEMENTS}

We would like to thank the Iñupiaq and Saint Lawrence Island Yupik language speakers and knowledge holders who generously shared their time and knowledge with us. We thank the staff from Kawerak, Inc. in Nome, Alaska, for their support and guidance, as well as Nome Eskimo Community, King Island Native Community, Solomon Traditional Council, Iñupiaq Village of Council, and Native Village of Utqiagivik. This work was supported by the Porter Family Foundation (Dartmouth Committee for the Protection of Human Subjects number 24335).

\section{REFERENCES}

Ash, A., Fermino, J.L.D., and Hale, K. 2001. Diversity in local language maintenance and restoration: A reason for optimism. In: Hinton, L., and Hale, K., eds. The greenbook of language revitalization in practice. San Diego: Academic Press. 19-35. https://doi.org/10.1163/9789004261723_003 
Barnhardt, C. 2001. A history of schooling for Alaska Native people. Journal of American Indian Education 40(1):1 - 30.

Barnhardt, R., and Kawagley, A.O. 2005. Indigenous knowledge systems and Alaska Native ways of knowing. Anthropology and Education Quarterly 36(1):8-23. https://doi.org/10.1525/aeq.2005.36.1.008

Brinkman, T.J., Hansen, W.D., Chapin, F.S., III, Kofinas, G., BurnSilver, S., and Rupp, T.S. 2016. Arctic communities perceive climate impacts on access as a critical challenge to availability of subsistence resources. Climatic Change 139(34):413-427.

https://doi.org/10.1007/s10584-016-1819-6

Chandler, M.J., and Lalonde, C.E. 2008. Cultural continuity as a protective factor against suicide in First Nations youth. Horizons 10(1):68-72.

Chapin, F.S., III, Trainor, S.F., Cochran, P., Huntington, H., Markon, C., McCammon, M., McGuire, A.D., and Serreze, M. 2014. Chapter 22: Alaska. In: Melillo, J.M., Richmond, T.C., and Yohe, G.W., eds. Climate change impacts in the United States: The Third National Climate Assessment. U.S. Global Change Research Program. Washington, D.C.: U.S. Government Publishing Office. 514-536. https://doi.org/10.7930/J00Z7150

Curtis, T., Kvernmo, S., and Bjerregaard, P. 2005. Changing living conditions, life style and health. International Journal of Circumpolar Health 64(5):442-450.

https://doi.org/10.3402/ijch.v64i5.18025

Dorian, N.C. 1981. Language death: The life cycle of a Scottish Gaelic dialect. Philadelphia: University of Pennsylvania Press. https://doi.org/10.9783/9781512815580

Easley, C., and Kanaqlak (Charles, G.P). 2005. Boarding school: Historical trauma among Alaska's Native people. Anchorage: National Resource Center for American Indian, Alaska Native, and Native Hawaiian Elders, University of Alaska Anchorage. https://www.uaa.alaska.edu/academics/institutionaleffectiveness/departments/center-for-advancing-facultyexcellence/documents/boarding-school-historical-traumaamong-alaska-s-native-people.pdf

Euskirchen, E.S., McGuire, A.D., Kicklighter, D.W., Zhuang, Q., Clein, J.S., Dargaville, R.J., Dye D.G., et al. 2006. Importance of recent shifts in soil thermal dynamics on growing season length, productivity, and carbon sequestration in terrestrial high-latitude ecosystems. Global Change Biology 12(4):731-750.

https://doi.org/10.1111/j.1365-2486.2006.01113.x

Fishman, J.A. 1965. Who speaks what language to whom and when. La Linguistique 1(2):67-88.

- 1991. Reversing language shift: Theoretical and empirical foundations of assistance to threatened languages. Clevedon, United Kingdom: Multilingual Matters.

Fitzgerald, C.M. 2017. Understanding language vitality and reclamation as resilience: A framework for language endangerment and 'loss.' Language 93(4):e280-e297.

https://doi.org/10.1353/lan.2017.0072
Forbes, B.C., Stammler, F., Kumpula, T., Meschtyb, N., Pajunen, A., and Kaarlejärvi, E. 2009. High resilience in the YamalNenets social-ecological system, west Siberian Arctic, Russia. Proceedings of the National Academy of Sciences of the United States of America 106(52):22041-22048. https://doi.org/10.1073/pnas.0908286106

Gal, S. 1979. Language shift: Social determinants of linguistic change in bilingual Austria. New York: Academic Press.

Gearheard, S., Matumeak, W., Angutikjuaq, I., Maslanik, J., Huntington, H.P., Leavitt, J., Kagak, D.M., Tigullaraq, G., and Barry, R.G. 2006. "It's not that simple": A collaborative comparison of sea ice environments, their uses, observed changes, and adaptations in Barrow, Alaska, USA, and Clyde River, Nunavut, Canada. AMBIO: A Journal of the Human Environment 35(4):203-211.

https://doi.org/10.1579/0044-7447(2006)35[203:INTSAC]2.0. $\mathrm{CO} ; 2$

Gearheard, S.F., Holm, L.K., Huntington, H., Leavitt, J.M., Mahoney, A.R., Opie, M., Oshima, T., and Sanguya, J., eds. 2013. The meaning of ice: People and sea ice in three Arctic communities. Hanover, New Hampshire: International Polar Institute Press.

George, J.C., Huntington, H.P., Brewster, K., Eicken, H., Norton, D.W., and Glenn, R. 2004. Observations on shorefast ice dynamics in Arctic Alaska and the responses of the Iñupiat hunting community. Arctic 57(4):363-374.

https://doi.org/10.14430/arctic514

Grenoble, L.A., and Whaley, L.J. 1998. Toward a typology of language endangerment. In: Grenoble, L.A., and Whaley, L.J., eds. Endangered languages: Language loss and community response. Cambridge: Cambridge University Press. 22 -54. https://doi.org/10.1017/CBO9781139166959.003

___ 2006. Saving languages: An introduction to language revitalization. Cambridge: Cambridge University Press.

Grimes, B.F. 2001. Global language viability. In: Sakiyama, O., ed. Endangered languages of the Pacific Rim. Lectures on endangered languages 2. From Kyoto conference 2000, Osaka: ELPR. 45-68.

Hale, K., Krauss, M., Watahomigie, L.J., Yamamoto, A.Y., Craig, C., Jeanne, L.M., and England, N.C. 1992. Endangered languages. Language 68(1):1-42.

https://doi.org/10.2307/416368

Hansen, W.D., Brinkman, T.J., Leonawicz, M., Chapin, F.S., III, and Kofinas, G.P. 2013. Changing daily wind speeds on Alaska's North Slope: Implications for rural hunting opportunities. Arctic 66(4):448-458.

https://doi.org/10.14430/arctic4331

Harrison, K.D. 2007. When languages die: The extinction of the world's languages and the erosion of human knowledge. Oxford: Oxford University Press.

Hinzman, L.D., Bettez, N.D., Bolton, W.R., Chapin, F.S., III, Dyurgerov, M.B., Fastie, C.L., Griffith, B., et al. 2005. Evidence and implications of recent climate change in northern Alaska and other Arctic regions. Climatic Change 72(3):251-298. https://doi.org/10.1007/s10584-005-5352-2 
Hornberger, N.H. 1998. Language policy, language education, language rights: Indigenous, immigrant, and international perspectives. Language in Society 27(4):439-458.

https://doi.org/10.1017/S0047404500020182

Hovelsrud, G.K., Poppel, B., van Oort, B., and Reist, J.D. 2011. Arctic societies, cultures, and peoples in a changing cryosphere. AMBIO: A Journal of the Human Environment 40(Suppl. 1):100-110. https://doi.org/10.1007/s13280-011-0219-4

Huntington, H.P., Quakenbush, L.T., and Nelson, M. 2016. Effects of changing sea ice on marine mammals and subsistence hunters in northern Alaska from traditional knowledge interviews. Biology Letters 12(8): 20160198.

https://doi.org/10.1098/rsbl.2016.0198

IPCC (Intergovernmental Panel on Climate Change). 2013. Climate change 2013: The physical science basis. Contribution of Working Group I to the Fifth Assessment Report of the Intergovernmental Panel on Climate Change. Stocker, T.F., Qin, D., Plattner, G.-K., Tignor, M., Allen, S.K., Boschung, J., Nauels, A., Xia, Y., Bex, V., and Midgley, P.M., eds. Cambridge: Cambridge University Press. 1535 p. https://www.ipcc.ch/report/ar5/wg1/

Jorgensen, J.G. 1978. A century of political and economic effects on American Indian society, 1880-1980. Journal of Ethnic Studies 6(3):1-82.

Kaplan, L. 2003. Inuit snow terms: How many and what does it mean? In: Trudel, F., ed. Building capacity in Arctic societies: Dynamics and shifting perspectives. Proceedings of the Second IPSSAS Seminar, 26 May-6 June 2003, Iqaluit, Nunavut. Montreal: CIÉRA -- Faculté des sciences sociales Université Laval. 263-270.

Kimmerer, R.W. 2002. Weaving traditional ecological knowledge into biological education: A call to action. BioScience 52(5):432-438.

https://doi.org/10.1641/0006-3568(2002)052[0432:WTEKIB]2. $0 . \mathrm{CO} ; 2$

Krauss, M.E. 2007. Native languages of Alaska. In: Miyaoka, O., Sakiyama, O., and Krauss, M.E., eds. The vanishing voices of the Pacific Rim. Oxford: Oxford University Press. 406-417.

Krauss, M., Holton, G., Kerr, J., and West, C.T. 2011. Indigenous peoples and languages of Alaska. Fairbanks: Alaska Native Language Center; Anchorage: Institute of Social and Economic Research, University of Alaska Anchorage. http://www.uaf.edu/anla/map

Krupnik, I., and Müller-Wille, L. 2010. Franz Boas and Inuktitut terminology for ice and snow: From the emergence of the field to the "Great Eskimo vocabulary hoax." In: Krupnik, I., Aporta, C., Gearheard, S., Laidler, G.J., and Holm, L.K., eds. SIKU: Knowing our ice. Documenting Inuit sea-ice knowledge and use. Dordrecht, Netherlands: Springer. 377-400.

Krupnik, I., Aporta, C., Gearheard, S., Laidler, G.J., and Holm, L.K., eds. 2010. SIKU: Knowing our ice. Documenting Inuit sea-ice knowledge and use. Dordrecht, Netherlands: Springer. $377-400$.

https://doi.org/10.1017/S0032247410000641
Leonard, W.Y. 2012. Framing language reclamation programmes for everybody's empowerment. Gender and Language 6(2):339-367. https://doi.org/10.1558/genl.v6i2.339

Maffi, L. 2005. Linguistic, cultural, and biological diversity. Annual Review of Anthropology 34:599-617. https://doi.org/10.1146/annurev.anthro.34.081804.120437

Marino, E. 2012. The long history of environmental migration: Assessing vulnerability construction and obstacles to successful relocation in Shishmaref, Alaska. Global Environmental Change 22(2):374-381. https://doi.org/10.1016/j.gloenvcha.2011.09.016

McIvor, O., and Rorick, C.L. 2017. "NETOLNEW, one mind, one people": Studying adult Indigenous language learners in mentor-apprentice language learning programs in Canada. Paper presented at American Association of Applied Linguistics 2017 Annual Conference, 18-21 March 2017, Portland, Oregon.

McIvor, O., Napoleon, A., and Kerissa, M.D. 2009. Language and culture as protective factors for at-risk communities. International Journal of Indigenous Health 5(1):6-25. https://doi.org/10.18357/ijih51200912327

Nettle, D., and Romaine, S. 2000. Vanishing voices: The extinction of the world's languages. Oxford: Oxford University Press.

Pullum, G.K. 1991. The great Eskimo vocabulary hoax and other irreverent essays on the study of language. Chicago: University of Chicago Press.

Regier, T., Carstensen, A., and Kemp, C. 2016. Languages support efficient communication about the environment: Words for snow revisited. PloS ONE 11(4): e0151138. https://doi.org/10.1371/journal.pone.0151138

Romaine, S. 2008. Linguistic diversity, sustainability, and the future of the past. In: King, K.A., Schilling-Estes, N., Fogle, L., Lou, J.J., and Soukup, B., eds. Sustaining linguistic diversity: Endangered and minority languages and language varieties. Washington, D.C.: Georgetown University Press. 7-21.

Simpson, L.R. 2004. Anticolonial strategies for the recovery and maintenance of Indigenous knowledge. The American Indian Quarterly 28(3-4):373-384.

https://doi.org/10.1353/aiq.2004.0107

Stanford, J.N., and Whaley, L.J. 2010. The sustainability of languages. International Journal of Environmental, Cultural, Economic, and Social Stability 6(3):111-122. https://doi.org/10.18848/1832-2077/CGP/v06i03/54784

Stroeve, J.C., Serreze, M.C., Holland, M.M., Kay, J.E., Maslanik, J., and Barrett, A.P. 2012. The Arctic's rapidly shrinking sea ice cover: A research synthesis. Climatic Change 110(34):1005-1027. https://10.1007/s10584-011-0101-1

Sumaila, U.R., Cheung, W.W.L., Lam, V.W.Y., Pauly, D., and Herrick, S. 2011. Climate change impacts on the biophysics and economics of world fisheries. Nature Climate Change 1(9):449-456. https://doi.org/10.1038/nclimate1301 
Tester, F.J., and McNicoll, P. 2004. Isumagijaksaq: Mindful of the state: Social constructions of Inuit suicide. Social Science \& Medicine 58(12):2625-2636.

https://doi.org/10.1016/j.socscimed.2003.09.021

Treuer, A. 2001. Introduction: We're not losing our language. In: Treuer, A., ed. Living our language: Ojibwe tales \& oral histories: A bilingual anthology. St. Paul: Minnesota Historical Society Press. 5-14.

Trumbull, E., Rothstein-Fisch, C., Greenfield, P.M., and Quiroz, B. 2001. Bridging cultures between home and school. A guide for teachers. New York: Routledge. https://doi.org/10.4324/9781410604958

UNESCO Ad Hoc Expert Group on Endangered Languages 2003. Language vitality and endangerment. Document submitted to the International Expert Meeting on UNESCO Programme Safeguarding Endangered Languages, 10-12 March 2003, Paris, France.

http://www.unesco.org/new/fileadmin/MULTIMEDIA/HQ/ CLT/pdf/Language_vitality_and_endangerment_EN.pdf
Watt-Cloutier, S. 2015. The right to be cold: One woman's story of protecting her culture, the Arctic and the whole planet. Toronto: Penguin Canada.

Wolfe, P. 2006. Settler colonialism and the elimination of the Native. Journal of Genocide Research 8(4):387-409. https://doi.org/10.1080/14623520601056240

Youngblood Henderson, J.(S). 2000. Ayukpachi: Empowering Aboriginal thought. In: Battiste, M, ed. Reclaiming Indigenous voice and vision. Vancouver: University of British Columbia Press. 248-278.

Zimmerman, M.A., Ramirez, J., Washienko, K.M., Walter, B., and Dyer, S. 1998. Enculturation hypothesis: Exploring direct and protective effects among Native American youth. In: McCubbin, H.I., Thompson, E.A., Thompson, A.I., and Fromer, J.E., eds. Resiliency in ethnic minority families, Vol. 1: Native and immigrant American minority families. Thousand Oaks, California: Sage. 199-220. 